\title{
EDUKASI PERENCANAAN KEUANGAN RUMAH TANGGA PADA IBU-IBU PKK DI DESA JATIMULYO KOTA MALANG
}

\author{
Susmita Dian Indiraswari ${ }^{1}$, Dimas Emha Amir Fikri Anas ${ }^{2}$ \\ ${ }^{1.2}$ Universitas PGRI Kanjuruhan Malang \\ E-mail : susmita@unikama.ac.id¹,dimas@unikama.ac.id²
}

\section{Submitted : 09 Juli 2021 Accepted: 24 Agustus 2021 Published: 31 Agustus 2021}

\begin{abstract}
Abstrak: Perencanaan keuangan rumah tangga tidak sesederhana seperti yang dibayangkan dibandingkan dengan mengelola keuangan perusahaan. Keuangan rumah tangga merupakan dasar dari suatu konsep perencanaan keuangan yang bersifat luas, dikarenakan dalam pengelolaan keuangan rumah tangga dibutuhkan tidak sekedar intuisi tetapi juga perlu edukasi yang memadai. Perencanaan keuangan rumah tangga yang kurang matang akan berdampak terhadap suatu tatan social pada tingkat dasar. Seorang ibu rumah tangga khususnya sering disebut sebagai pengelola keuangan utama, akan tetapi setiap ibu rumah tangga memiliki latar belakang pendidikan yang berbeda-beda. Tujuan dari kegiatan pengabdian masyarakat ini adalah untuk memberikan edukasi seputar perencanaan keuangan rumah tangga khususnya kepada ibu rumah tangga melalui kegiatan PKK (Pemberdayaan Kesejahteraan Keluarga). Hasil pengabdian masyarakat menunjukkan ibu ibu rumah tangga khususnya menunjukkan antusiasme yang sangat tinggi terlihat dari banyaknya pertanyaan yang diajukan dan diskusi seputar pengalaman dalam perencanaan keuangan rumah tangga yang selama ini sudah dilakukan. Konsep dalam membuat suatu perencanaan keuangan rumah tangga secara sederhana dapat dengan mudah diaplikasikan oleh ibu ibu rumah tangga tersebut.
\end{abstract}

Kata Kunci: Perencanaan, Keuangna Rumah Tangga 


\section{PENDAHULUAN}

Pandemi global saat ini sangat mempengaruhi perekonomian Indonesia bahkan dunia. Indonesia merupakan negara yang sedang berkembang. Saat ini Indonesia sedang melaksanakan pembangunan disegala sektor. Pembangunan tersebut dilakukan oleh pemerintah Indonesia dengan tujuan menyetarakan Indonesia dengan negaranegara lainnya (Mulyani \& Nurdin, 2018) - Adanya perubahan globalisasi membawa dampak dan pengaruh bagi perekonomian di negara Indonesia saat ini.

Upaya yang harus dilaksanakan dalam merubah perilaku masyarakat di Indonesia yang konsumtif yaitu dengan cara memberikan pengetahuan tentang pengelolaan keuangan rumah tangga. Adanya kegiatan tesebut diharapkan dapat menerapkan pengelolaan keuangan sederhana secara efisien dan efektif. Hal tersebut diharapkan dapat berdampak terhadap masyarakat agar merubah pola hidup yang konsumtif kearah manajemen keuangan yang lebih baik. Perubahan pada pola hidup yang demikian, diharapkan dapat merubah mindset masyarakat agar menyisihkan sebagian pendapatan mereka untuk ditabung dan diinvestasikan (Mulyani \& Nurdin, 2018).

Perencanaan Keuangan yang dikemukakan oleh Otoritas Jasa Keuangan (OJK) memberikan penjelasan cara untuk merencanakan keuangan yang baik, Langkahlangkah yang digunakan untuk merencanakan keuangan tersebut, yaitu 1) kenali terlebih dahulu kondisi keuangan, 2) menentukan keinginan, 3) menentukan keinginan utama. Setiap keinginan tidak dapat terpenuhi dikarenakan adanya suatu keterbatasan. Salah satu keterbatasan tersebut adalah kemampuan finansial. Perlu adanya proritas keinginan yang mendesak. Adanya kesadaran dalam berinvestas sangat diperlukan dalam manajemen keuangan rumah tangga. Edukasi berinvestasi pada masyarakat tidak hanya berfokus pada perencanaan keuangan keluarga, namun seorang istri/suami juga mampu mengelola keuangan rumah tangga dengan tepat.

Salah satu hal yang cukup penting yaitu penyusunan anggaran rumah tangga. Tahap penyusunan anggaran adalah inti dari pengelolaan keuangan dalam memenuhi kebutuhan sekarang dan kebutuhan selanjutnya. Anggaran rumah tangga yang sehat yaitu jumlah pendapatan lebih besar dari pada jumlah konsumsi. Jika jumlah konsumsi melebihi jumlah pendapatan akan menyebabkan defisit keuangan (Finatariani, dkk., 2020). Pelatihan dalam menyusun manajemen rumah tangga perlu diterapkan pada struktur yang paling kecil yakni seorang ibu.

Pelatihan untuk ibu-ibu dalam mengelola keuangan rumah tangga dilakukan melalui pelatihan pada suatu organisasi yang disebut Pemberdayaan Kesejahteraan Keluarga (PKK). Kelompok PKK merupakan kumpulan dari para ibu rumah tangga. Di sisi lain, ibuibu rumah tangga tersebut mengisi waktu mereka dengan beberapa kegiatan sosial misalnya arisan, pengajian dan kegiatankegiatan PKK (Pemberdayaan Kesejahteraan Keluarga) lainnya di lingkungan masyarakat (Ariningrum, dkk., 2020).

Kegiatan Pengabdian Kepada Masyarakat ini dilaksanakan dalam bentuk sosialisasi atau pelatihan yang bertema manajemen keuangan rumah tangga. Sasaran atau target dari dari pelatihan ini adalah ibu-ibu anggota PKK di Kelurahan Jatimulyo. Target dari adanya kegiatan pelatihan atau sosialisasi yaitu menyalurkan ilmu pengetahuan tentang manajemen keuangan rumah tangga, yang meliputi wawasan tentang perencanaan pengeluaran keuangan, wawasan tentang pos-pos pengeluaran rumah tangga dan tips dalam mengelola manajemen keuangan rumah tangga. Berdasarkan fenomena ini, maka dapat diambil permasalahan yang ada 
pada suatu rumah tangga yaitu keterampilan dalam manajemen keuangan rumah tangga oleh suami/istri. Keterampilan tersebut perlu ditingkatkan agar tercipta kesadaran tentang pentingnya manajemen keuangan rumah tangga dan pencatatan sederhana.

\section{TINJAUAN PUSTAKA}

\subsection{Manajemen Keuangan dalam Rumah}

\section{Tangga}

Manajemen keuangan dalam rumah tangga merupakan kegiatan pengelolaan sumber daya keuangan dalam rumah tangga. Pengelolaan keuangan rumah tangga yang dimaksud adalah pengelolaan terhadap jumlah pendapatan dan pengeluaran keluarga. Jadi, manajemen keuangan dalam rumah tangga merupakan suatu seni untuk mengelola keuangan rumah tangga atau keluarga oleh seorang ibu. Pengelolaan tersebut dimaksudkan agar terciptanya kondisi keluarga yang sejahtera dan tentram. Managemen keuangan dalam rumah tangga menjadi suatu keharusan dan tidak dapat diremehkan. Manajemen keuangan rumah tangga memiliki implikasi yang luas dikarenakan tidak hanya diri sendiri yang terlibat, namun juga pihak keluarga lainnya (Siregar, 2019).

\subsection{Pemberdayaan Kesejahteraan Keluarga (PKK)}

Pemberdayaan Kesejahteraan Keluarga (PKK) adalah suatu organisasi untuk mensejahterakan masyarakat khususnya perempuan. Tujuan dari organisasi PKK ini adalah memperbaiki dan meningkatkan kedudukan masyarakat dan mewujudkan keluarga yang beriman dan bertaqwa kepada Tuhan Yang Maha Esa, berakhlaq mulia dan berbudi luhur, sehat, maju dan mandiri, berkesetaraan dan berkeadilan gender serta berkesadaran hukum dan lingkungan.

\section{METODE PENELITIAN}

Teknik yang digunakan untuk melakukan pelatihan adalah dengan cara menjalankan diskusi dan koordinasi kepada ketua PKK dan anggota PKK Kelurahan Jatimulyo. Kordinasi tersebut berkaitan dengan pelaksanaan dan target pada masyarakat wilayah setempat. Alur pelaksanaan kegiatan ini bermula dari peserta pelatihan yang diberikan pemahaman mengenai benefit dan pentingnya manajemen keuangan rumah tangga. Selanjutnya, peserta tersebut diberikan wawasan bagaimana alur untuk menyusun laporan keuangan secara simpel. Selanjutnya para peserta dilatih untuk membuat draft manajemen keuangan rumah tangga dengan format sudah disiapkan. Hal tersebut bertujuan untuk mempermudah pembuatan laporan keuangan yang dapat memanifestasikan planning keuangan rumah tangga secara baik dan tepat. Alur pelatihan pengabdian masyarakat di Desa Jatimulyo adalah:

\section{Tahapan penjadwalan:}

a. Pengadaan kelengkapan administrasi; bahan dan materi.

b. Pengadaan media dan fasilitas penunjang.

c. Pengadaan undangan untuk peserta, word, dan penyusunan template sebagai materi.

d. Pengadaan panitia kegiatan pengabdian masyarakat, membagi tugas dan tanggung jawab.

e. Penetapan lokasi pelatihan yang dilakukan di salah satu rumah warga Kelurahan Jatimulyo, Kota Malang

\section{Tahapan Pelaksanaan}

a. Pendahuluan

b. Pemaparan materi

1) Pemaparan pentingnya dalam melakukan pencatatan dan pembukuan keuangan rumah tangga

2) Pengantar perencanaan keuangan rumah tangga

3)Perencanaan dalam keuangan rumah tangga 
4) Cara pencatatan manajemen keuangan rumah tangga

5) Pelaksanaan pencatatan untuk keuangan rumah tangga

c. Metode :

1.) Diskusi, Ceramah, Workshop dan Tanya jawab

\section{Tahapan Ulasan}

a. Ulasan hasil pelatihan

b. Diskusi, Tanya jawab

c. Penutupan dan sesi dokumentasi

\section{HASIL DAN PEMBAHASAN}

Kegiatan edukasi perencanaan keuangan rumah tangga dilakukan pada tanggal 17 Desember 2020. Dalam kegiatan PKK (Pemberdayaan Kesejahteraan Keluarga) dihadiri kurang lebih 20 orang yang dilaksanakan di salah satu rumah warga setempat. Pada sesi pertama edukasi disampaikan oleh Ibu Susmita dengan materi seputar proporsi dalam perencanaan pengeluaran keuangan dan pada sesi kedua oleh Bapak Dimas tentang hal hal yang dapat dilakukan dalam perencanaan keuangan rumah tangga sebagai berikut :

\subsection{Membuat Pos-Pos Pengeluaran}

Contohnya, penghasilan istri 2 juta, suami 3 juta. Setiap pasangan perlu menghitung rasio pengeluaran. Berikut ini yang disarankan dalam pengelolaan keuangan rumah tangga.

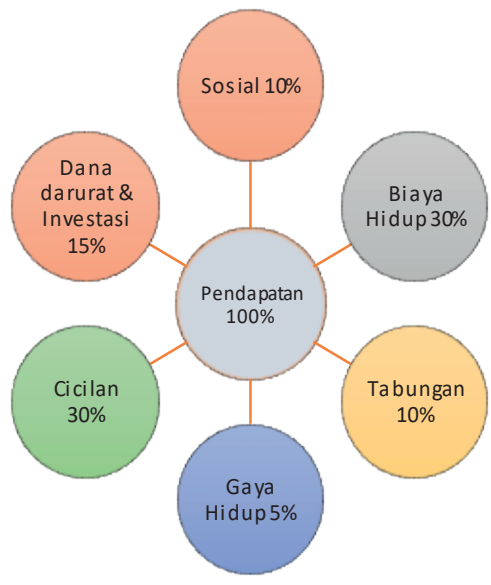

1. Sosial 10\%. Setiap pasangan perlu menganggarkan $10 \%$ dari pendapatan untuk dana sosial. Yang termasuk dana sosial adalah dana untuk bersedekah, uang arisan, iuran RT, dan kebutuhan sosial lainnya. Jika penghasilan suatu keluarga 5 Juta, maka Rp 500.000,- dari penghasilan itu harus dialokasikan untuk kebutuhan sosial.

2. Dana Darurat dan Investasi $15 \%$. Sisihkan dana $15 \%$ dari penghasilan untuk dana darurat dan investasi. Jika penghasilan pasangan 5 juta, maka harus menganggarkan uang sebanyak Rp 750.000,- untuk dana darurat dan Investasi.

3. Cicilan 30\%. Selanjutnya, anggarkan 30\% dari penghasilan untuk membayar cicilan. Cicilan yang dimiliki tidak boleh lebih dari $30 \%$ dari penghasilan. Hal ini adalah tolok ukur keuangan suatu rumah tangga yang sehat. Jika pendapatan suatu keluarga adalah 5 Juta Rupiah, maka pasangan tersebut memiliki uang sebesar $\mathrm{Rp}$ 1.500.000,untuk mencicil. Uang cicilan ini lebih baik digunakan untuk mencicil properti, seperti rumah atau kendaraan. Jangan gunakan uang cicilan untuk kebutuhan non primer, misalkan HP atau perhiasan.

4. Biaya Hidup 30\%. Alokasikan dana sebesar 30\% dari penghasilan untuk biaya hidup sehari-hari. Gunakan uang sebesar Rp 1.500.000,- untuk makan, membayar tagihan listrik, air, dan juga belanja bulanan.

5. Tabungan $10 \%$

Selain dana darurat dan investasi, alokasikan juga pendapatan keluarga untuk tabungan. Untuk menabung, anggarkan dana sebesar $10 \%$ dari penghasilan. Jika suatu keluarga memiliki penghasilan sebesar 5 Juta, maka keluarga tersebut harus menabung sebesar $\mathrm{Rp}$ 500.000,setiap bulannya. Uang tabungan ini bisa digunakan untuk membeli kebutuhan tersier. Misalnya, keluarga tersebut ingin

Gambar 1. Pos-Pos Pengeluaran Manajemen Rumah Tangga 
membeli kulkas baru atau liburan bersama akhir tahun.

6. GayaHidup5\%.Janganlupamenganggarkan uang untuk biaya bersenang-senang. Anggarkan 5\% dari pendapatan suatu keluarga untuk biaya bersenang-senang. Jika pendapatan suatu pasangan adalah 5 juta, maka keluarga tersebut memiliki jatah sebesar Rp 250.000,- setiap bulan untuk bersenang-senang.

\subsection{Tips Perencanaan Keuangan Rumah}

\section{Tangga}

Jika suatu keluarga telah membuat pos-pos pengeluaran sesuai dengan penghasilan dan kebutuhan. Kini suatu keluarga tersebut bisa mengikuti beberapa tips mengelola keuangan rumah tangga di bawah ini

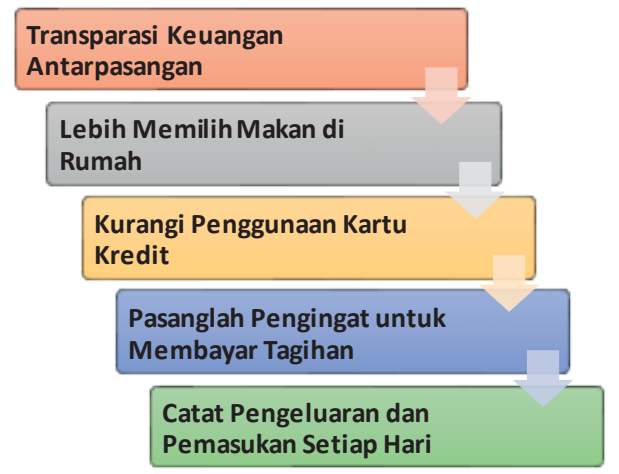

Gambar 2. Tips Perencanaan Keuangan Rumah Tangga

1. Transparasi Keuangan Antarpasangan. Salah satu hal paling penting dalam mengelola keuangan rumah tangga adalah adanya transparasi keuangan. Suami dan istri harus sama-sama terbuka mengenai gaji bulanan yang didapat, tabungan yang dimiliki, juga hutang yang mungkin masih menjadi beban. Adanya transparasi keuangan antara suami dan istri dapat dengan lebih cermat dalam melakukan perencanaan dan mengatur keuangan keluarga.

2. Lebih Memilih Makan di Rumah. Ini adalah cara untuk menghemat pengeluaran rumah tangga. Daripada jajan atau makan di luar, biasakan untuk memasak di rumah. Ini bisa memangkas kebutuhan harian suatu keluarga.

3. Kurangi Penggunaan Kartu Kredit. Kurangilah penggunaan kartu kredit. Menggunakan kartu kredit memang memudahkan dalam melakukan suatu transaksi. Akan tetapi, bila suatu pasangan atau keluarga tidak bisa mengontrol pemakaian kartu kredit, maka dapat menimbulkan masalah keuangan bagi keluarga.

4. Catat Pengeluaran dan Pemasukan Setiap Hari. Dari segi perencanaan, jika suatu pasangan sudah mempersiapkannya dengan baik. Namun, itu tidak cukup. Pasangan tersebut juga harus memastikan bahwa pemasukan dan juga pengeluaran keuangan rumah tangga berjalan sesuai dengan rencana. Buatlah catatan setiap mendapatkan uang. Catat juga pengeluaran keluarga setiap hari. Dengan begitu, suatu pasangan tersebut bisa tahu kapan anggaran akan mulai habis, sehingga pasangan tersebut dapat lebih hemat.

5. Pasanglah Pengingat untuk Membayar Tagihan. Setiap bulan ada tagihan rutin yang harus dibayarkan. Oleh karena itu, setiap pasangan perlu memasang pengingat untuk membayar tagihan. 


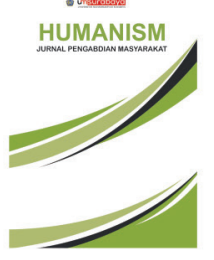

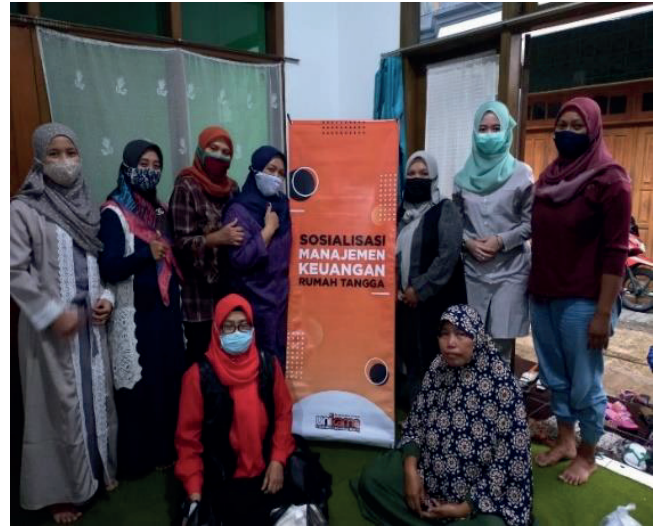

Gambar 3. Pelatihan Manajemen Keuangan Rumah Tangga bersama Ibu Susmita

Pada masa pandemi ini banyak keluhan yang dilontarkan para ibu-ibu rumah tangga di Kelurahan Jatimulyo dalam mengatur keuangan rumah tangga mereka. Kegiatan pelatihan ini sangat dirasakan manfaatnya oleh para peserta yang terdiri dari ibu-ibu rumah tangga di kelurahan Jatimulyo. Manfaat yang dirasakan setelah adanya kegiatan pelatihan manajemen keuangan rumah tangga ini, mereka mendapatkan solusi untuk mengatur pos-pos keuangan rumah tangga. Manfaat lainnya yang dirasakan oleh para ibu-ibu rumah tangga setelah mengikuti kegiatan pelatihan ini, mereka mendapatkan inspirasi untuk menambah jumlah pendapatan mereka di masa pandemi ini.

\section{KESIMPULAN}

Pandemi COVID-19 tidak hanya menyerang masalah kesehatan pada masyarakat, namun juga menyerang masalah perekonoman. Hal tersebut ditandai dengan kondisi perekonomian masyarakat yang semakin terpuruk. Adanya keterpurukan perekonomian tersebut berimbas pada keuangan rumah tangga masyarakat. Kegiatan ini bertujuan untuk memberikan pelatihan manajemen keuangan rumah tangga kepada ibu-ibu rumah tangga agar mereka dapat memahami dan membuat pos-pos pengeluaran rumah tangga secara tepat. Selain itu, kegiatan

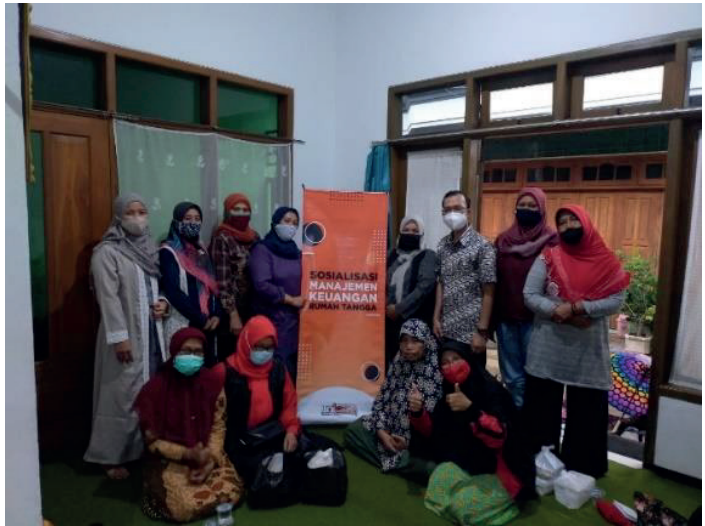

Gambar 4. Pelatihan Manajemen Keuangan

Rumah Tangga bersama Bapak Dimas

ini juga memberikan tips kepada ibu-ibu rumah tangga dalam mengelola keuangan rumah tangganya.

\section{DAFTAR PUSTAKA}

Ariningrum, dkk. (2020). Pelatihan Keuangan Sederhana Bagi Ibu Pkk Di Desa Sukajaya Lempasing Kabupaten Pesawaran. Communnity Development Journal, 1(3), 389-394.

Finatariani, Dkk. (2020). Pengelolaan Keuangan Keluarga Dan Pengenalan Dasar-Dasar Investasi Menuju Keluarga Mandiri Bagi Ibu-Ibu Majelis Taklim Al Auladiyah,

Tangerang Selatan. Dedikasi Pkm Unpam, $1(1), 132-139$.

Mulyani \& Nurdin. (2018). Pelatihan Perencanaan Keuangan Keluarga Bagi Ibu Ibu Pkk Desa Cimenyan Kabupaten Bandung. Jurnal Abdimas Bsi, 1(2), 259-267.

Siregar, B.U. (2019). Ibu Rumah Tangga Dalam Manajemen Keuangan Keluarga. Jurnal Kajian Gender Dan Anak, 3(2). 